\title{
FACING THE GLOBAL ECONOMIC CRISIS: THE CASE OF SWEDISH HEAVY VEHICLE SUBCONTRACTORS
}

\author{
ROBERT RADWAY \\ ANDREAS HELMERSSON \\ Jönköping University
}

\begin{abstract}
In this paper, we investigate organisational responses to an economic crisis within a group of seven subcontractors in the Swedish heavy vehicle industry. Although the participating firms had similar exposures to an abrupt and severe shift in demand, their performances during the crisis varied extensively. One year after the crisis began, some firms were still encountering financial problems threatening their survival, yet others had orchestrated a recovery that was generating healthy cash flows. Evaluation of in-depth interviews with key organisational members and standardised financial indicators suggests that the subcontractors' performances in the crisis were determined by their ability to attain and evaluate 'deep knowledge' from stakeholders and 'wide knowledge' from other external actors. Hence, our findings not only demonstrate an opportunity to extend existing research on crisis management but also indicate that the subcontractors' performances in the economic crisis were related to the implementation of dynamic capabilities.
\end{abstract}

During the first half of 2008, business was generally flourishing for Swedish heavy vehicle subcontractors. The capacity utilisation within the industry was reaching a record-high level and the projections of the two major Swedish original equipment manufacturers (OEMs) of heavy vehicles, Volvo Trucks and Scania, were very promising. In fact, the second quarter (Q2) of 2008 was the best quarter in the entire history of Volvo Trucks, which is the world's second largest heavy truck brand (Volvo Group1, 2008). As a consequence, many subcontractors were having troubles to deliver the increasing order levels and were, under pressure from the OEMs, making significant investments to increase production capacity. Hence, whilst the global car industry was facing severe problems caused by the financial crisis of 2007 and a world of rising gas prices and increased awareness of traffic emissions (New York Times, 2008), the Swedish heavy vehicle industry appeared to be safe and sound.

However, on the $24^{\text {th }}$ of October when Volvo Trucks and Scania presented their third quarter results, it was evident that this optimistic prospect was drastically inaccurate. Most remarkably, Volvo Trucks announced that orders of heavy trucks in Europe had fallen from 21,948 (Q2) to 115 
(Q3) (Volvo Group2, 2008). In addition, Scania revealed a decrease of incoming orders on the European market from 9,287 (Q2) to 5,268 (Q3) (Scania Interim Report, 2008). Although Volvo Trucks had laid off around 1,400 employees the previous month, this came as a shock to the Swedish subcontractors. The common belief had been that the OEMs were making adjustments to 'normal' market conditions after a year of exceptional demand, but in reality the financial crisis had began manifesting itself across the globe. The effects of the financial crisis on the automotive industry were first felt in America, but quickly spread throughout the world. In essence, this entailed that credit markets froze which constrained potential customers from financing purchases of motor vehicles (for more information on how the financial crisis affected the global automotive industry, see KPMG International, 2008; New York Times, 2008).

Among the Swedish heavy vehicle subcontractors, the severity and unpredictability of this shift caused alarming declines in cash flows and essentially paralysed production over a night. And the troubles continued; in Q4, Scania's incoming orders decreased with a further 98 percent, whilst Volvo Trucks saw cancellations induce an additional decline of 82 percent (Scania, 2009; Volvo Group, 2009). As a result, in less than four months, the Swedish heavy vehicle industry went from enjoying the upside of operating leverage to feeling dramatically the risk of high fixed costs.

In August, 2009, the Swedish automotive subcontractors (both light and heavy vehicles) had laid off more than 20,000 of its 85,000 employees. In addition, 15 subcontractors had filed for bankruptcy, 9 had entered reconstruction, and 4 had left the country ${ }^{1}$. More interesting, whilst some firms were still loosing SEK millions each month, others had orchestrated a recovery that was generating SEK millions of positive cash flow per month. Given that many of these organisations had similar exposures to the crisis, these diverse performances are perplexing. Thus, in this research, we set out to investigate how Swedish heavy vehicle subcontractors dealt with the economic crisis facing them in the fall of 2008, and understand why their performances during the crisis varied so extensively².

However, although this research project was triggered by an empirical perplexity, theoretical pre-conceptions have played a purposeful role in our research process. We have used theory not as a standardised inquiry on a small number of organisations but as an injection of inspiration for identifying new patterns and developing further insights. Consequently, the article is structured to parallel this research process. Following the empirical setting (above), we begin by describing our theoretical pre-understanding which was used as a foundation for interpreting and explaining the empirical case. Second, we outline the method for collecting and analysing empirical data, and discuss the implications of our particular approach to inquiry. Third, we portray the similarities and differences in performances, perceptions, preparations, and responses among our sample of organisations. Finally, we link the subcontractors' behaviour to their performances in the crisis and discuss both theory and empirical data in light of one another. Overall, the intent of this article is to identify patterns and develop an understanding of organisational responses to the economic crisis in the Swedish heavy vehicle industry.

1 These figures have been accumulated from reports in the popular press by the Swedish Automotive Industry Association.

2 For a more comprehensive introduction to the automotive industry, see Appendix I on page 20. 


\section{THEORETICAL FRAMEWORK}

An economical crisis poses major threats to the viability of companies; as credit becomes less available and customers less willing to spend, firms encounter severe difficulties in producing sales and are forced to cut costs to survive. Paradoxically, focussing too much on the short-term needs and cutting down on core competencies may undermine sustainable competitive advantage and long-term success of the firm. However, whilst business cycles and related macroeconomic policies have drawn enduring academic attention within the fields of economics, it is only during the past two decades that scholars have began exploring firm-level responses to economic recessions (Pearce and Michael, 2006). Moreover, firm-level studies on economic crises are very few and many questions concerning the effectiveness of organisational capabilities under such periods remain to be answered (Grewal and Tansuhaj, 2001).

In other words, there is no established body of literature that deals specifically with organisational responses to economic crises. Thus, in this section, we summarise past findings and a sense of current thinking within research areas that hold potential to help our understanding and explanation of the empirical case.

\section{Crisis Management Research (CMR)}

An organisational crisis can be set in motion by a number of factors but is generally defined as 'a low probability, high impact situation that is perceived by critical stakeholders to threaten the viability of the organisation' (Pearson and Clair, 1998: 66). CMR suggests that an organisation's ability to cope with crises depends on its preparations and responses. More specifically, the preparation phase involves identifying and interacting with stakeholders and potential victims to prevent crises from happening and affecting stakeholders, whilst the response phase aims to minimise the losses of stakeholders that result from a crisis (Shrivastava, 1993).

Scholars have found that successful management in these two phases requires accurate assumptions and knowledge with regards to stakeholders' behaviour during crises. This is because attaining trustworthy information about the external environment is crucial for making favourable decisions in times of a crisis (Ulmer, 2001). Following this line of reasoning, Alpaslan et al. (2009) recently expatiated a 'stakeholder model of crisis management', which contends that firms' approaches to crises ought to be characterised by preparations and responses that involve as many stakeholders as possible. This is because it allows them to bring several perspectives and diverse knowledge into understanding a crisis and shape action plans accordingly.

More specifically, Alpaslan et al. (2009) draw on a rich body of empirical and theoretical literature in suggesting that firms who have established stakeholder relationships based on trust and mutual efforts are more likely to prevent and respond more effectively to crises because they benefit from more open and accurate flows of critical information. This requires managers to prepare for a variety of crises, be devoted to building relationships with all their stakeholders, and - in the heat of a crisis - ensure that critical information reaches the right stakeholders. In this approach to crisis management, it is essential to recognise that external actors are valued with regards to their stake in the organisation rather than by the organisation's stake in them. In addition, involving internal, external, and less powerful stakeholders in crisis management teams is likely to generate better decision-making. A stakeholder approach to crisis management, therefore, 
enables managers to construct a more accurate portrayal of what is happening in the external environment and allow them to detect and respond more quickly to early warning signals (Alpaslan et al., 2009).

However, because CMR tend not to focus on crises caused by economical dynamics (but rather natural disasters, information sabotage, terrorist attacks, moral and ethical standards being subject to public scrutiny, and so forth), it provides little insight into how firms can manage respond effectively to changes in the business climate. Dynamic capability theory, on the other hand, provides insight into how organisations can modify the way in which they operate in order to respond quickly to rapid changes in the marketplace. Consequently, in order to complement our understanding of how firms can survive and prosper under conditions of change in the external environment, we turn to dynamic capability theory next.

\section{Dynamic Capability Theory (DCT)}

During the 1990s, DCT emerged as an extension of the 'resource based view' within strategic management research ${ }^{3}$. In essence, DCT argues that building sustainable competitive advantage require firms to develop capabilities that enable combining, transforming, and renewing resources into unique clusters. These capabilities are dynamic in the sense that they rely on firms to continually 'integrate, build, and reconfigure internal and external competences to address rapidly changing environments' (Teece et al., 1997: 516). Yet, it is instructive to note that, a dynamic capability is not a source of long-term competitive advantage per se, but rather the ability to build new forms of competitive advantage over time (Eisenhardt and Martin, 2000; Bowman and Ambrosini, 2003).

A basic tenet of DCT is that historical forces play an essential role in the strategic management of organisations. This notion, named path dependency, entails that a firm's current position (i.e., the sum of its resources and capabilities) is a function of the path it has travelled, which, in turn, influences its future decisions and capability of occupying markets and taking up new technologies (Teece et al., 1997). In other words, historical paths define the spectrum of contemporary and future choices available to the firm, or as Dosi (1995: 11-12) puts it:

... An integral part of the explanation of 'where we are going' or 'why we are here' is the account of 'where we come from'... History, so to speak, solidifies into structures which constrain future developments.

DCT was initially addressing firms in hypercompetitive and rapidly changing environments (see Teece et al., 1997). However, later studies have argued that dynamic capabilities vary with market dynamism. More specifically, in a highly turbulent market, dynamic capabilities are expected to be highly experiential and involve fragile processes that rely on the ability to create new knowledge and repetitive execution to produce adaptive, but unpredictable outcomes. In a moderately dynamic market, on the other hand, dynamic capabilities are expected to be located in routines that rely extensively on existing knowledge and linear execution with mainly predictable outcomes (Eisenhardt and Martin, 2000; Fichman, 2000). Hence, it is possible for dynamic capabilities to operate in relatively stable environments as well.

It has also been argued that the implementation of dynamic capabilities rely heavily on the

3 For a more comprehensive account of how dynamic capability theory emerged, see Appendix // on page 21. 
actions taken by senior managers (Adner and Helfat, 2003; Eisenhardt and Martin, 2000). This is because dynamic capabilities emerge from path-dependent processes (i.e., learning mechanisms) that are 'impacted by the organisational processes, systems, and structures that the enterprise has created to manage its business in the past' (Teece, 2007: 1346). This also implies that dynamic capabilities appear to be largely vested in how managers perceive the external environment. Thus, firms in similar environments may display diverse dynamic capabilities because of their managers' interpretations of what is happening in the business climate (Aragon-Correa and Sharma, 2003).

Finally, dynamic capabilities are typically built over a long period of time, involve long-term commitments to specialised resources, and are conducive to long-term business performance (Winter, 2003; Wang and Achmed, 2007). But there is also a short-term perspective of dynamic capabilities: they are instruments allowing the firm to constantly renew its resource stock so that it can capitalise on temporary market opportunities and Schumpeterian rents. In other words, dynamic capabilities are means of sustaining advantage 'through the achievement of a continuous sequence of temporary, short-lived advantages' (Ambrosini and Bowman, 2009: 43).

\section{Microfoundations of Dynamic Capability Theory}

The implementation of dynamic capabilities essentially requires firms to combine a set of 'simpler' capabilities. Some of these may be elementary and must therefore be learned first (Brown and Eisenhardt, 1997). In a recent contribution, David Teece outlined these capabilities, named microfoundations of DCT, by disaggregating dynamic capabilities into the capacity of (a) 'sensing' opportunities and threats, (b) 'seizing' opportunities, and (c) managing threats and reconfiguration. We turn to each of these capabilities below.

Sensing opportunities and threats. In order to detect threats and shape new opportunities, organisations must analyse the environment in which they operate. Whilst investments in research and related processes are necessary, this ability is highly dependent on processes of scanning, creating, learning, and interpreting. The microfoundations of this ability include directing internal R\&D, tapping external knowledge with regards to innovation and developments in science and technology, and identifying how customer needs and markets are changing (Teece, 2007). In other words, firms must investigate latent demand, technological possibilities, development of industries and markets, and how this affects customer needs (both visible and hidden) as well as supplier and competitor responses. To do this, firms must search for information externally from actors such as customers, suppliers, complementors, universities, government agencies, and so forth.

Seizing opportunities. The next step involves addressing and capitalising on new opportunities as soon as they have been detected by developing new products, processes, or services. In this ability, the microfoundations involve selecting business models, creating decisionmaking protocols, selecting firm boundaries, and building loyalty (Teece, 2007). Put differently, firms ability to seize opportunities is highly dependent on consistently building and improving technological competences and interrelating assets so that investments can be made when an opportunity is identified. It requires accurate decisions regarding how, when, and where to invest, and the art of designing appropriate and novel business models.

Managing threats and reconfiguration. In order to avoid troublesome and threatening paths and retain evolutionary fitness (and thus maintain competitiveness), firms must reconfigure their intangible and tangible assets as well as organisational structures. When a firm is successful it 
will instigate certain routines to achieve operational efficiency, which usually are adequate until there is a shift in the external environment. The microfoundations of this ability involves managing knowledge (e.g., intellectual property, know-how integration, and knowledge transfer), cospecialisation (i.e., using resources that enhance one another), governance (e.g., incentives and agency issues), and decentralised leadership (Teece, 2007).

In summary, dynamic capabilities develop resource configurations which create new ways of generating value, and their advantage lies in putting them into use sooner and more accurately than rivals (Eisenhardt and Martin, 2000). The microfoundations of dynamic capabilities include skills that allow the organisation to integrate knowledge from outside and within its boundaries and adapt to changing environments. They also embrace the firm's capacity to 'shape the ecosystem it occupies, develop new products and processes, and design and implement viable business models' (Teece, 2007: 1320). However, it is worth re-emphasising that, whilst such procedures are likely to be critical to business performance and are key elements of dynamic capabilities, they are not dynamic capabilities themselves (Ambrosini and Bowman, 2009). Hence, such procedures do not represent a direct (but rather an indicative) connection between implementation and existence of dynamic capabilities. Yet, organisations displaying sensing, seizing, and reconfiguration capabilities are likely to hold the infrastructure required for quick adaptations and ability to capitalise on short-term opportunities.

\section{METHOD}

The effects of economical swings on firms' performances are, among other things, determined by industry and geographical exposures; industries have diverse price elasticities and regions are affected with varying dignity and at different times (Pearce and Michael, 2006). In order to investigate other factors influencing crisis performance, however, we collaborated with the Swedish Automotive Industry Association ('FKG') to attain assistance in selecting a group of Swedish subcontractors that had similar exposures to the crisis and were as operationally proximal as possible. Moreover, the collaboration with FKG played a central role in ensuring participants' anonymity and attaining access to the subcontractors' financial performances. This is because subcontractors commonly work on long-term arrangements - where pricing negotiations with the OEMs are crucial - and keep financial data strictly confidential as they can be used by the OEMs to claim lower prices ${ }^{4}$.

Initially, eleven subcontractors were included in the sample but as we realised that additional factors had influenced their exposures to the crisis (e.g., a significant share of turnover being derived from spare parts rather than original components), the sample was gradually refined to include seven organisations. Prior to the crisis, these subcontractors derived at least 65 percent of turnover from producing original heavy vehicle components of which at least 50 percent came from either Scania, Volvo Trucks, or both. Consequently, as displayed in Table I on page 7, the participating organisations saw incoming orders decline with 60-80 percent.

Data collection. To investigate how the organisations experienced and reacted to the economic crisis, in-depth interviews were performed with chief executives, operating officers, and

4 To protect participants' anonymity, all names have been changed and specific characteristics of some organisations have been disguised. 
marketing officers. More specifically, a semi-structured interview format was used to enable directing discussions into pre-identified areas of inquiry (e.g., preparatory actions, immediate responses, and learning outcomes), whilst at the same time allowing participants to have a major influence on what was discussed (Ericsson, 2001). The length of the interviews ranged from at least 1.5 hours to as much as 2.5 hours and were preserved through audio recordings (when permitted by the participants) and/or detailed field notes. In addition, standardised instrumentation was used to assess organisational performances in the crisis. This was performed by retrieving historical financial data from Affärsdata (Swedish database) and recent financial figures directly from participants during interviews to construct performance indicators such as break-even point, total sum of losses, layoff percentage, as well as changes in turnover and net income.

Data analysis. We began the analysis of each subcontractor by asking the question 'How did this organisation interpret, prepare, and respond to the economic crisis?'. Using this as a foundation, we compared the findings to their corresponding performances and across the entire sample of organisations. In this phase, it was found that two small sized organisations (Speedefic and Heavyenx) and two medium sized organisations (Weavy and Macufact) represented distinctively diverse strategies. More interesting, Weavy and Macufact experienced identical declines of incoming orders (70 percent of turnover), yet their performances were diametrically opposite among the medium sized subcontractors. In the same way, despite encountering very similar declines of incoming orders (60 and 63 percent of turnover), the performances of Speedefic and Heavyenx represented opposite ends among the small firms. Given the puzzling nature of these findings, we felt inclined to deepen our understanding of these organisations and made additional phone calls to their chief executives who were asked to reconstruct particular experiences. Thus, whilst data from all seven subcontractors were used to identify and shape a model of adaptive behaviour, these four organisations were used to break down the complexity of particular behaviours and understand their ensuing outcomes.

Finally, the data analysis was combined with frequent theoretical discussions; by spiralling between empirical data and theory in several repetitive loops, we sought to enhance our understanding of theory and data in light of each other. In this way, our study deliberately falls between both an inductive and a deductive approach - known as abduction - whereby the focus has been to develop the empirical area of application and refine existing theories (Alvesson and Sköldberg, 2000) 5 .

TABLE I: EXPOSURES TO CRISIS

\begin{tabular}{lcccc}
\hline Subcontractor & $\begin{array}{c}\text { Exposure to the } \\
\text { heavy vehicle } \\
\text { industry }\end{array}$ & $\begin{array}{c}\text { Tier 1 } \\
\text { production }\end{array}$ & $\begin{array}{c}\text { Change of } \\
\text { incoming orders } \\
\text { due to crisis }\end{array}$ \\
\cline { 2 - 4 } Speedefic & $68 \%$ & $95 \%$ & $-63 \%$ \\
Hueme & $100 \%$ & $100 \%$ & $-80 \%$ \\
Heavyenx & $90 \%$ & $80 \%$ & $-60 \%$ \\
Weavy & $65 \%$ & $65 \%$ & $-70 \%$ \\
Contrec & $70 \%$ & $100 \%$ & $-60 \%$ \\
Subfoorce & $90 \%$ & $100 \%$ & $-70 \%$ \\
Macufact & $65 \%$ & $40 \%$ & $-70 \%$ \\
\hline
\end{tabular}

5 A more detailed account of our reasoning when selecting financial indicators is available in Appendix III on page 22. 


\section{FINDINGS}

Heavy vehicle subcontractors are hired by large prime contractors (i.e., OEMs) to perform a specific task as part of the overall production of heavy vehicles. In order to operate efficiently, the OEMs provide their subcontractors with forecasts of production for the coming 48 weeks. This information is updated and transferred into the subcontractors' IT systems on a weekly basis, and is used by the subcontractors to plan their internal production. In the fall of 2008 , the dilemma was that these production forecasts were nowhere near the actual flow of future orders. And, as previously expressed, the common belief - that the Swedish heavy vehicle industry was safe and sound - was driven by these optimistic forecasts. So, how did the subcontractors respond when the forecasts dissolved quickly on the $24^{\text {th }}$ of October?

\section{Common Behaviours}

There were some apparent commonalities in how the organisations reacted to the crisis. A 'crisis team' was appointed in all the organisations (usually consisting of the management team and a few additional organisational members) to manage the situation. These teams first tried to overview the situation by contacting external actors such as customers, suppliers, and FKG to attain information. Second, they evaluated the information by assessing its implications on their business (e.g., cost and break-even analysis). Third, decisions were taken to adjust the organisation accordingly, resulting in actions such as investment and purchasing stoppage, freezing/reducing wages, laying off personnel, and various measures to increase liquidity. However, it is vital to recognise that, this process was not executed as a single and linear procedure, but rather occurred intermittently and continually for several months. For instance, many organisations made decisions to lay off personnel shortly after the shock, but as more information was attained, additional layoffs were announced. This adaptive behaviour was reported at all seven subcontractors and has been summarised in Figure I below.

\section{FIGURE I: COMMON BEHAVIOUR FOR ADAPTATION}

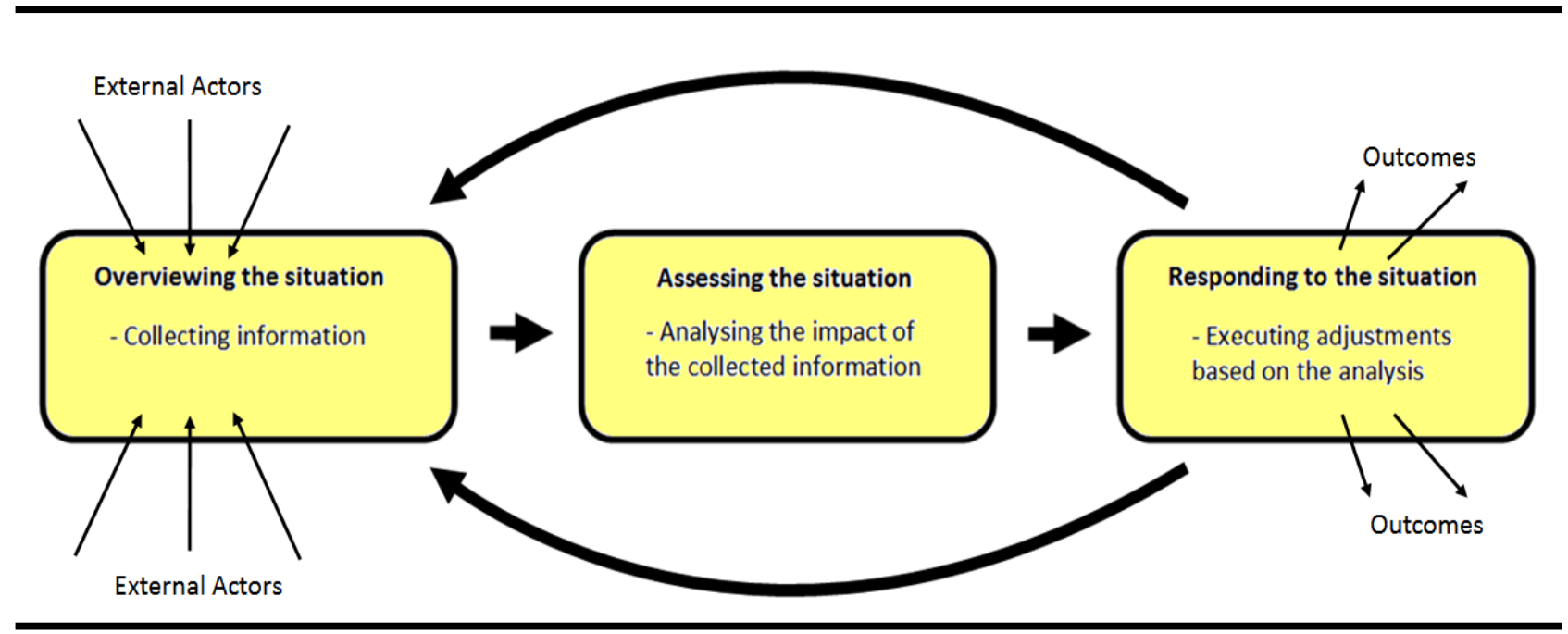




\section{Four Diverse Performances}

As displayed in Table II on page 11, the sample consists of three small and four medium sized organisations. Among the medium sized organisations, Weavy demonstrated the strongest performance as it reached an operating break-even level (EBITDA) ahead of all other participating organisations, kept aggregated losses comparatively low (3.5 percent of turnover 2008 or 138 percent of average net income before the crisis), and is expected to achieve a net income around 2.9 percent of turnover in 2009. In contrast, Macufact is, at the time of writing, still loosing SEK millions each month and has (so far) incurred aggregated losses amounting to 5.1 percent of turnover 2008 or 1,150 percent of average net income before the crisis. Besides, the organisation is expected to make a net loss amounting to approximately 16.7 percent of turnover in 2009 .

Among the small sized organisations, Speedefic's performance was prominent as the organisation maintained a large portion of its turnover, kept aggregated losses relatively low (136 percent of average net income before the crisis), and is not expected to make an annual loss in 2009. Heavyenx, on the other hand, is expected to incur losses of around 7 percent of turnover in 2009 and has made losses corresponding to 275 percent of average net income before the crisis. In summary, although these four organisations had similar exposures to the economic crisis and behaved similarly in trying to adapt (see Figure I on page 8), their performances in the crisis were not resembling - they varied extensively (see Figure I/ below). Consequently, in sharpening the differences in their adaptive behaviours, this section describes what happened in each of these four organisations as the crisis unfolded. The cases are written to assimilate the organisations' varying backgrounds and actions taken during the crisis. They also represent the participants' perceptions of being part of a firm critically exposed to an economic shift.

A complete breakdown. Macufact is a medium sized firm who traditionally has been focussing on maximising operational efficiency and satisfying customer needs by delivering high quality components. Prior to the crisis, the firm performed an average annual net income exceeding SEK two millions (2005 - 2007) and increased its turnover by 20 percent in 2007 . The CEO of Macufact described the crisis as an 'unexpected storm that come out of nowhere and hit the organisation during a very unfavourable time'. Why did this conventional organisation fail so dramatically in responding to the crisis?

FIGURE II: DISPARATE PROFITABILITIES

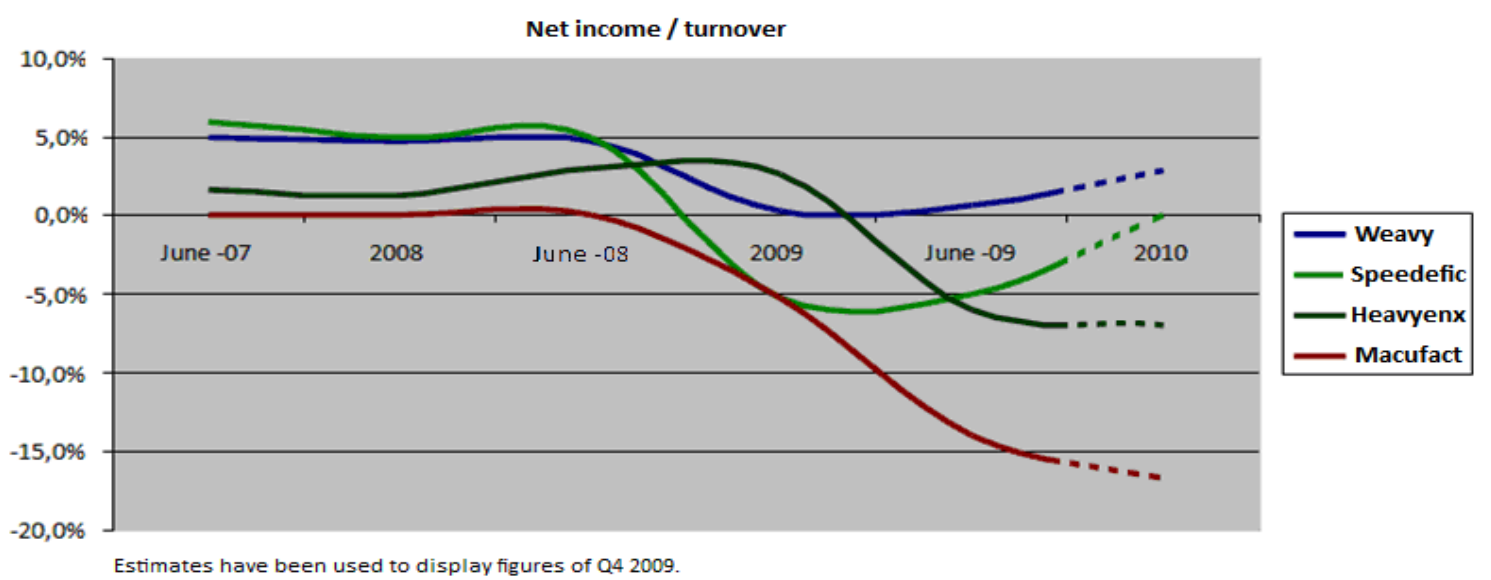


In 2007, Macufact experienced stern pressures from the Swedish OEMs to increase production capacity, but as its financial status was rather weak (solvency $=11$ percent, cash liquidity $=65$ percent) it was difficult to finance such investments. In the beginning of the following year, however, a foreign group acquired the firm which provided access to capital. Shortly after, Macufact launched its largest investment program in the history of the organisation (amounting to approximately SEK 40 millions) in order to string along with the OEMs' future growths. In conjunction with this acquisition, the new head office - located in a different part of the world took over the decision-making concerning new costumers and developing the business. According to Macufact's CEO, the business climate was perceived to be stable and 'the idea was to allow us [Macufact] to focus on developing internal processes, whilst head office would use its broader knowledge and contacts to identify new opportunities'.

As the crisis unfolded, panic spread throughout Macufact's organisation. It had not seen any indications of the economic crisis and the parent company did not provide any assistance when the problems escalated. Consequently, Macufact sought for information through its established communication channels. This gave rise to intensified dialogues with customers, suppliers, and FKG as well as more attention to what was reported in the media. The goal was to continue meeting the needs of existing customers, but Macufact experienced significant difficulties in understanding how the environment was changing and assessing its implications on their operations. 'We were hoping that the future outlook would be better after the OEMs had presented their Q4 results. When we realised that those results were even worst, we knew that we were in big trouble', the CEO explained.

Macufact made two minor layoffs in November, but these proved much too small. Consequently, significant layoffs were frequently made during the fall of 2009. Nevertheless, the firm did not reduce its fixed costs in time and was declared bankrupt in May. One week later, new owners injected capital into a newly formed entity, which essentially meant that the organisation continued to operate under a new name. 'We have learned that we cannot rely solely on our customers. We must develop better processes for creating our own forward planning', the CEO replied to quires about learning outcomes from the crisis.

Hanging in there. Heavyenx is a small sized firm who prides itself on having extensive market knowledge. Despite being a significantly smaller firm than Macufact, the firm displayed a similar average annual net income (around SEK two millions) in the years 2005 - 2007, and increased its turnover by 22 percent in 2007. In the summer of 2008, the firm saw indications of a severe downturn, yet it remained notably passive during the crisis. How could this profitable and marketoriented organisation incur such sizeable losses in the crisis?

The CEO of Heavyenx began worrying about what appeared to be a 'normal' recession in June, 2008. Having worked his entire life within the automotive industry, he had detected disbelieves concerning the OEMs' forecasts from several people within his wide social network (both in Sweden and internationally). 'When a close friend of mine, who lives in the United States, told me that his firm was starting to see lower order levels within the heavy vehicle industry, I realised that the financial crisis was likely to affect our business as well', he explained. Prior to the crisis, Heavyenx did not use a standardised format for market and business analysis. Rather, the management team would discuss changes in the marketplace during informal meetings which the CEO used in making decisions concerning the direction of the firm on his own. In this way, the 
Radway and Helmersson

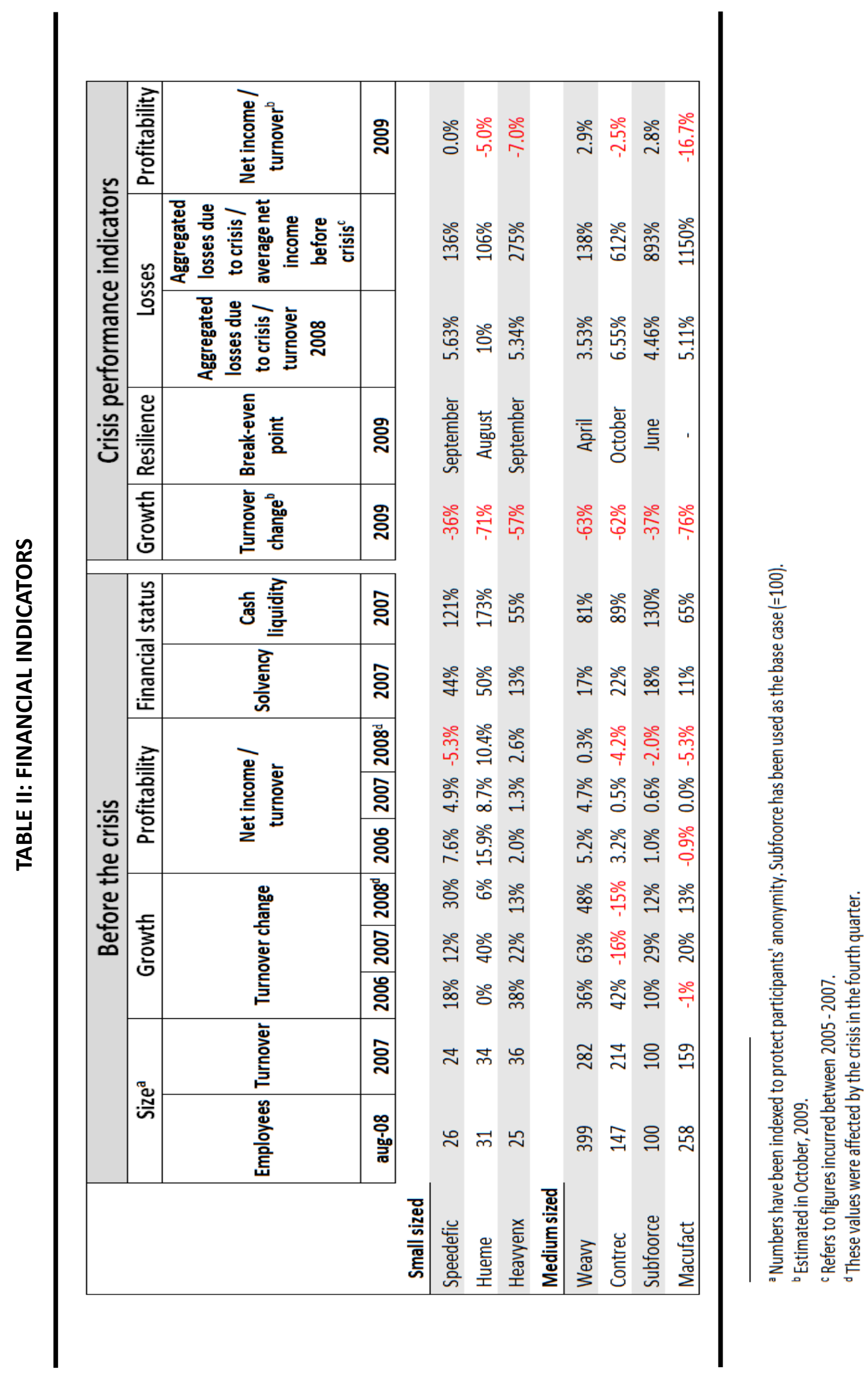


CEO had a major role in scanning the environment, making him 'the spider in the web' as the CMO expressed it.

As the economic crisis unravelled, the CEO was the only one who gathered information about what was happening. He received extensive information from various friends within the industry, which complemented intensified communication with customers, suppliers, the FKG, and competitors. In addition, Heavyenx had for many years been working with a partner university, which also proved useful for attaining information concerning macro economic data. However, Heavyenx did not act upon the collected information instantly. 'Our job is to produce what the OEMs tell us to produce. We are not supposed to plan ahead with regards to production levels', the CEO replied when asked why the organisation did not respond to the crisis earlier on. Hence, whilst Heavyenx was able to foresee a downturn (which turned out to be a crisis) and overview the situation quite well during the crisis, it had to create new processes for coordinating assessment and appropriate responses among the crisis team members as no established routines existed.

The CEO made a decision to layoff all the temporary employees in August, 2009. However, a crisis team was not appointed until the end of October to take further action. The crisis team made around 30 percent of the layoffs in December, but the remaining 70 percent of layoffs were not realised until April, 2009. Hence, whilst Heavyenx was quite well prepared for the crisis (due to layoffs of temporary employees), the ensuing assessment and decision-making processes were slow which caused significant losses in 2009 (see Figure II on page 9). In other words, despite collecting extensive information about the market through his social network, the CEO saw the lowered demand as a problem for the OEMs. He contended that the firm could not have handled the crisis in any better way: 'We have to deliver what the OEMs ask for, that is why we could not make additional adjustments at an earlier stage'.

Prospecting for new opportunities. Speedefic is a small sized firm who displayed a strong financial status prior to the crisis (solvency $=44$ percent, cash liquidity $=121$ percent). It also performed a substantial average annual net income (amounting to SEK three millions) between $2005-2007$, and increased its turnover by 12 percent in 2007 . Speedefic put a massive fate in its largest and most important customer (Scania) when completely trusting their forecasts before the crisis, yet the firm is expected to break-even in 2009 and has managed to attain new customers during the crisis. How did this organisation manage to deal with the crisis so effectively despite remaining remarkably unresponsive prior to its duration?

Building strong relations to customers and suppliers as well as striving to find smart solutions by simplifying and optimising products' design is mandate for any heavy vehicle subcontractor. A couple of years ago, however, Speedefic made a decision to work more actively with its marketing and sales efforts. The management team established processes for gathering, monitoring and evaluating external information. For instance, the CMO was appointed to create a business intelligence report on a monthly basis that was used to support decision making within the management team; technical and management consultants were hired to assist the firm in identifying new processes and technologies applicable to the business; more organisational members were included in evaluating potential investments; standardised instrumentation was used to attain and categorise news about the industry and particular firms. 'The idea was to become increasingly proactive and not become too comfortable in our long-term partnerships', the $\mathrm{CMO}$ explained. 
In the summer of 2008 , concerns spread among Speedefic's management team as they feared that the rapid decline of demand within the car industry would affect the heavy vehicle industry as well. Yet, because their largest customer gave no signs of a decline, it was concluded that no measures were to be taken. 'We had a meeting with Scania who assured us that production levels were going to increase, so we were hoping that they were right', the CMO replied to queries about Speedefic's late response to the crisis. The firm continued to operate without any adjustments throughout 2008 which produced significant losses (see Figure II on page 9). However, once Speedefic realised that the decreasing order levels were not a seasonal down swing (which is common during that time of the year), the firm's established routines for collecting and evaluating external data proved favourable. In January, the management team appointed a crisis team and swift measures were taken as wages were frozen and around 60 percent of layoffs were realised one week later.

The crisis team cooperated with both consultants and the firm's bank in analysing the external information which made it easier to assess its implications on the business. Moreover, although the evaluation of external information primarily focussed on assessing layoffs and increasing working capital, Speedefic maintained its marketing and sales processes. None of the employees within the marketing and sales department were made redundant and whilst other firms cut down on expenses by not participating in trade fairs during the crisis, Speedefic saw the crisis as an opportunity to attain new customers within other segments and industries. 'Our customer base is larger than it has ever been. We are in better position now than we were before the crisis', said the CMO.

A remarkable readjustment. Weavy is a medium sized firm who has been focussing on strategic work and business development processes for the past two decades. The firm displayed a strong profitability coming in to the crisis and increased its turnover by a whopping 48 percent in 2007. Early on in 2008, the firm made several investments to keep up with the OEMs' forecasts which engendered a rather low level of equity (solvency $=17$ percent, cash liquidity $=81$ percent), yet the firm is expecting to make a net income around SEK 13 million in 2009. How could this firm orchestrate coordinated actions that made its performance in the crisis outshine the other sample organisations?

Weavy works actively with producing business cycle analyses and scenario planning to identify how the business environment is changing. This is achieved by collecting and elaborating with a wide spectrum of external data. In contrast to the other sample organisations, Weavy continuously gathers data from key manufacturers and suppliers in related industries, monthly projections and macro economic analyses from banks, a handful of databases (e.g., historical industry data), the Swedish Central Bank, around 10 various news subscriptions (e.g., industry information), trends in oil prices and newly registered heavy vehicles, reports and analyses from Global Insight, and so forth. Whilst this information is primarily collected by the CEO, there are around 10-15 people (the management team and all sales people) who contribute with specific information concerning their area of specialisation. These people are also involved in analysing the external information on a regular basis which normally serves the purpose of identifying and making decisions regarding new business opportunities.

When the crisis unfolded in October, Weavy had been anticipating a downturn for several months. Analyses were conducted to prepare for varying rates and levels of decline in incoming 
orders. The worst case scenario allowed the organisation to absorb a decline of 17 percent without making any layoffs at all, but the severity of the decline came as a shock (the worst case scenario was far from enough). Consequently, a crisis team was appointed the day after Scania and Volvo had presented their Q3 figures. Although the information sought for in the external search strategy shifted slightly, the crisis team was able to follow the established routines for collecting, assessing and responding to external information. As a result, prompt measures were taken; 50 percent of layoffs were made already in November and the remaining 50 percent of layoffs in December as one of the factories was closed down completely. In addition, the CEO explained that 'an evaluation system for determining competence levels among employees was in place prior to the crisis which made it easy to negotiate layoffs with the union'.

Moreover, because Weavy was expecting a downturn, the firm had depreciated its machines and equipment aggressively and could now increase its depreciation periods to improve working capital. 'I do not think that we were the only ones to question the OEMs' optimistic forecasts, but I

\section{TABLE III: SUMMARY OF ADAPTIVE PROCESSES}

\begin{tabular}{|c|c|c|c|}
\hline & $\begin{array}{l}\text { Overviewing the situation } \\
\text { - external sources used }\end{array}$ & $\begin{array}{l}\text { Assessing the situation } \\
\text { - analytical process }\end{array}$ & $\begin{array}{c}\text { Responding to the situation } \\
\text { - measures taken }\end{array}$ \\
\hline 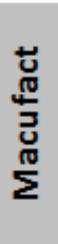 & $\begin{array}{l}\text { Customers, suppliers, FKG, and the } \\
\text { popular press. }\end{array}$ & $\begin{array}{l}\text { Formed a crisis group, performed } \\
\text { cost and break-even analyses, and } \\
\text { assessed layoffs subjectively. }\end{array}$ & $\begin{array}{l}\text { Stopped investments/purchasing, } \\
\text { devoted efforts to lower working } \\
\text { capital, froze salaries, realised the } \\
\text { first } 25 \% \text { of layoffs before December, } \\
\text { realised the last } 75 \% \text { of layoffs } \\
\text { between January - May. }\end{array}$ \\
\hline 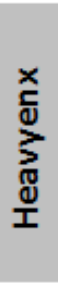 & $\begin{array}{l}\text { Customers, suppliers, FKG, the } \\
\text { popular press, competitors, } \\
\text { universities, and a wide social } \\
\text { network. }\end{array}$ & $\begin{array}{l}\text { Formed a crisis group, performed } \\
\text { cost and break-even analyses, and } \\
\text { assessed layoffs subjectively. }\end{array}$ & $\begin{array}{l}\text { Stopped investments/purchasing, } \\
\text { devoted efforts to lower working } \\
\text { capital, reduced salaries with } 15 \% \text {, } \\
\text { reduced working hours by } 20 \% \text {, } \\
\text { realised the first } 30 \% \text { of layoffs in } \\
\text { December - January, realised the last } \\
70 \% \text { of layoffs in April. }\end{array}$ \\
\hline 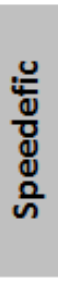 & $\begin{array}{l}\text { Customers, suppliers, FKG, the } \\
\text { popular press, industry newspapers, } \\
\text { competitors, trade fairs, and } \\
\text { technical and management } \\
\text { consultants. }\end{array}$ & $\begin{array}{l}\text { Formed a crisis group, performed } \\
\text { costs and break-even analyses with } \\
\text { technical and management } \\
\text { consultants, assessed layoffs } \\
\text { together with their bank (how many) } \\
\text { and subjectively on their own (who), } \\
\text { and created an action plan. }\end{array}$ & $\begin{array}{l}\text { Stopped investments/purchasing, } \\
\text { devoted efforts to lower working } \\
\text { capital, froze salaries, prioritised } \\
\text { marketing/sales department, realised } \\
\text { the first } 60 \% \text { of layoffs in January, } \\
\text { realised the last } 40 \% \text { of layoffs in } \\
\text { April. }\end{array}$ \\
\hline$\underset{3}{\stackrel{3}{\mathbb{J}}}$ & $\begin{array}{l}\text { Customers, suppliers, FKG, the } \\
\text { popular press, industry newspapers, } \\
\text { competitors, trade fairs, customers' } \\
\text { share information, prognoses from } \\
\text { related industries, Global Insight } \\
\text { (industry analyses), databases, macro } \\
\text { analyses from banks, Swedish Central } \\
\text { Bank, and oil price development. }\end{array}$ & $\begin{array}{l}\text { Formed a crisis group, performed } \\
\text { cost and break-even analyses, } \\
\text { assessed layoffs using an already } \\
\text { existing employee competence } \\
\text { evaluation system, adjusted their } \\
\text { business cycle analysis, and created } \\
\text { an action plan. }\end{array}$ & $\begin{array}{l}\text { Stopped investments/purchasing, } \\
\text { devoted efforts to lower working } \\
\text { capital, increased depreciation } \\
\text { periods, reduced salaries with } 15 \% \text {, } \\
\text { reduced working hours by } 20 \% \text {, } \\
\text { realised the first } 50 \% \text { of layoffs in } \\
\text { November, realised the last } 50 \% \text { of } \\
\text { layoffs in December. }\end{array}$ \\
\hline
\end{tabular}


do think we were among few companies who dared to make preparations before the crisis was evident. And that is why were able to make swift adjustments when the crisis began', said the CEO when asked why Weavy was able to manage the crisis in better way than other firms. Nevertheless, Weavy could have performed even better: 'Our analysis of the firm's crisis performance has shown that some investments made in 2008 were too large. You can always become better', the CEO contended.

In summary, the subcontractors' adaptive behaviour involved overviewing, assessing, and responding to external information. The four cases described above represent diverse approaches to, and implementation of, these processes (for a summary, see Table III on page 14). As the firms shared similar exposures to the abrupt demand shift, we suggest that these different approaches and implementations can be linked to their distinctive achievements in the crisis. Hence, in the next section, we organise and interpret these results in relation to existing research.

\section{DISCUSSION}

In the fall of 2008, the economic crisis in the heavy vehicle industry plunged the Swedish subcontractors into an unfamiliar situation. The purpose of this study was to investigate how the subcontractors acted under these circumstances and attempt to understand and explain their contrasting performances. Our collected data indicates that the subcontractors have utilised similar behaviours for adapting to the environmental shift and that their performances were contingent upon their ability to search for and act upon external information. The implications of these findings are discussed below.

Preparations and responses. Macufact's weak performance appears to derive from an inability to detect changes in the external environment and a lack of established decision-making processes for dealing with such changes. In another way, Heavyenx capacity for discovering (particularly through the CEO's wide social network) and preparing (by laying off hired personnel in August) for the demand shift engendered a strong performance early on. Yet, Heavyenx's slow assessment and decision-making processes caused significant losses during the subsequential phase of the crisis. In contrast to Heavyenx, Speedefic was not well prepared for the crisis as it followed the OEMs' forecasts exclusively (causing substantial losses early on), yet the firm's established routines for collecting and evaluating external data generated swift responses once the crisis was acknowledged (resulting in an impressive recovery in 2009). Finally, Weavy's strong achievements in the crisis were characterised by activities of foreseeing and preparing for the crisis as well as deep-rooted routines for responding swiftly to the external environment throughout the duration of the crisis. Thus, our interpretations support existing research on crisis management (see Shrivastava, 1993) in suggesting that the subcontractors' ability to cope with the economic crisis was dependent on their ability to (a) foresee and prepare for a decline in demand and (b) orchestrate responses minimising the losses caused by the crisis.

Moreover, gaining access to stakeholders' knowledge appears to have been a crucial element in the subcontractors' ability to understand the crisis and shape responses. This was apparent as customers and suppliers were reported to be the most valuable external information sources at all seven organisations. Another example of a valuable stakeholder relationship was Speedefic's cooperation with their bank, which, according to the $\mathrm{CMO}$, had a significant impact on 
their ability to attain 'deep' information and form adequate responses. However, whilst this indicates that Alpaslan et al.'s (2009) stakeholder theory of crisis management is applicable to crises caused by economical dynamics, there is also evidence suggesting that using other knowledge sources yields enhanced performance. For instance, Weavy's overall analysis of 'wide' external information (i.e., information from non-stakeholders) was not in line with the OEMs' forecasts, which is why the organisation began preparing for a downturn in advance. Hence, in light of these findings, we suggest that an essential portion of the subcontractors' performances in the economic crisis was the account of their ability to attain and evaluate (a) 'deep knowledge' from stakeholders such as customers, suppliers, and creditors as well as (b) 'wide knowledge' from additional actors such as firms in related industries, the Swedish Central Bank, and news/research organisations.

Sensing and seizing. Following the above reasoning, capabilities of sensing the environment and seizing opportunities have contributed to the subcontractors' performances in the crisis. In terms of sensing, our findings indicate that, using a single external information source (e.g., the customers' forecasts) may not be an adequate way to understand the business environment. Rather, using several knowledge sources widely and deeply appears to have enhanced organisations' ability to shape an accurate portrayal of the changes in external environment. In terms of seizing, on the other hand, the findings suggests that subcontractors with established processes and routines for implementing decisions based on external information were able to adjust the firm more rapidly. In addition, there appears to have been an interplay between sensing and seizing processes. For instance, Weavy was able to prepare for a decline (i.e., seize an opportunity - or actually, defend against a threat) not only because it had established processes for assessing external information but, more fundamentally, because accurate information was used in these processes. Put differently, Weavy was able to overcome biases and errors in their decision-making processes, and, as Teece (2007: 1334) notes, firms can achieve this by 'obtaining an outside view through review of external data'. Hence, we propose that achieving an intimate connection between sensing and seizing processes are likely to have enhanced the subcontractors' performances in the crisis.

The cases of Speedefic and Weavy also indicate that capabilities to sense and seize are likely to allow firms to maintain their marketing and sales efforts in times of an economic crisis, which, in turn, puts them in a strong position to gain market shares from other competitors who are forced to cut costs to survive (also argued in Pearce and Michael, 1997; Köksal and Özgül, 2007). Moreover, the cases of Heavyenx and Speedefic demonstrate the importance of the relationship between the CEO and business unit managers. In contrast to Heavyenx where the CEO was solely responsible for business development and strategic decisions, Speedefic involved several managers in constantly challenging current value-adding processes. This is also likely to have influenced Speedefic's ability (and thus, Heavyenx's inability) to seize opportunities (also argued in Chesbrough, 2006; Teece, 2007).

The findings discussed above are noteworthy considering that existing research on the microfoundations of dynamic capabilities are primarily focussing on sensing and seizing as capabilities for shaping innovation opportunities. The practices of open innovation (see Chesbrough, 2003), for instance, are relevant to sensing information about what is happening in the business environment. However, whilst it has been shown that using external knowledge 
sources yields enhanced innovative performance to a certain point (Laursen and Salter, 2006), crises are a hitherto unexplored area for such inquiries. Thus, because economical swings are becoming increasingly frequent (Pearce and Michael, 2006) and dynamic capability theory focuses on the firm's ability to combine, transform, and renew its resources in line with changes in its environment, we encourage scholars to further investigate the connection between economical dynamics and dynamic capabilities.

Perceptions and path dependencies. Among the subcontractors' executives, two diverse perceptions of the firm's role in the supply chain were identified. Whilst the executives at Macufact and Heavyenx considered the most important aspect of their business to be satisfying customer needs by delivering components as efficiently as possible, the executives at Speedefic and Weavy were primarily focussed on continually developing new ways of creating value. As a result, these firms had developed different processes - or mechanisms - of business development. When the crisis unfolded, however, the subcontractors' needs to attain external information increased. It was no longer sufficient to simply follow the OEMs' forecasts; the subcontractors had to collect, analyse, and respond to external information on their own. However, because these processes (i.e., overviewing, assessing, and responding to external information) are developed over time, firms who did not have such mechanisms in place prior to the crisis struggled. In contrast, firms who were used to collect external information for the purpose of identifying new business opportunities, were able to utilise the same information channels and internal processes to do this in the crisis (although they now focussed on managing the crisis). Hence, this implies that the subcontractors performances in the crisis were related to how their executives perceived the firm's role within the supply chain.

\section{CONCLUSION}

The economic crisis that hit the Swedish heavy vehicle industry in the fall of 2008 is complex from both a theoretical and a practical perspective. In this study, we set out to understand how the Swedish subcontractors tried to manage this situation effectively, and explain why their performances differed. Our findings showed that as the crisis unfolded, the subcontractors' adopted a similar behavioural pattern in trying to adapt to the new circumstances; all the sample organisations reported processes of collecting, analysing and responding to external information. However, our findings indicate that, the subcontractors' different performances in the crisis can be explained by their existing procedures for attaining and evaluating 'deep knowledge' from stakeholders and 'wide knowledge' from other external actors. Finally, the extent to which such procedures existed prior to the crisis is likely to be largely vested in how their executives perceived the firm's role within the supply chain.

These findings indicate that subcontractors demonstrating signs of dynamic capabilities were able to manage the economic crisis more effectively than others. However, as we have only investigated a small number of organisations, there are several questions that remain to be answered. Hence, we hope our research stimulates interest in the perplexing phenomena of economic crises and motivates more firm-level research on how dynamic capabilities can be used to address economical dynamics. 


\section{REFERENCES}

Adner, R. and Helfat, C. 2003. Corporate effects and dynamic managerial capabilities. Strategic Management Journal, 24: 1011-1025.

Alpaslan, C.M., Green, S.E. and Mitroff, I.I. 2009. Corporate Governance in the Context of Crises: Towards a Stakeholder Theory of Crisis Management. Journal of Contingencies and Crisis Management, 17(1): 38-49.

Alvesson,M. and Sköldberg, K. 2000. Reflexive Methodology. London: Sage.

Ambrosini, V. and Bowman, C. 2009. What are dynamic capabilities and are they a useful construct in strategic management?. International Journal of Management Reviews, 11(1): 29-49.

Aragon-Correa, J. and Sharma, S. 2003. A contingent resource-based view of proactive corporate environmental strategy. Academy of Management Review, 28: 71-88.

Bowman, C. and Ambrosini, V. 2003. How the resource-based and the dynamic capability views of the firm inform competitive and corporate level strategy. British Journal of Management, 14: 289-303.

Brown, S.L. and Eisenhardt, K. 1997. The art of continuous change: Linking complexity theory and time-paced evolution in relentlessly shifting organizations. Administrative Science Quarterly, 42(1): 1-34.

Chesbrough, H.W. 2003. The Era of Open Innovation. MIT Sloan Management Review, 44(3): 35-41.

Chesbrough, H.W. 2006. Why Companies Should Have Open Business Models. MIT Sloan Management Review, 48(2): 22-28.

Dosi, G. 1995. Hierarchies, markets and power: Some foundational issues on the nature of contemporary economic organizations. Oxford: Oxford University Press.

Eisenhardt, K. and Martin, J. 2000. Dynamic capabilities: what are they? Strategic Management Journal, 21: 11051121.

Ericsson, T. 2001. Sense making in organisations - towards a conceptual framework for understanding strategic change. Scandinavian Journal of Management, 17: 109-131.

Fichman, R.G.. 2000. The diffusion and assimilation of information technology innovations. In Robert W. Zmud (Ed.), Framing the Domains of IT Management Research: Glimpsing the Future Through the Past. Cincinnati: Pinnaflex Educational Resources.

Grewal, R. and Tansuhaj, P. 2001. Organizational capabilities for managing economic crises. Journal of Marketing, 65 : 67-80.

IHS Global Insight. 2008. Volvo Trucks Reports Plunging November Sales as Cancellations Outstrip Orders. [Online] Available at: http://www.ihsglobalinsight.com/SDA/SDADetail15320.htm [Accessed: November 27, 2009].

KPMG International. 2008. A rough road - The Effects of today's financial crisis on the global automotive industry. [Online] Available at: http://www.kpmg.eu/docs/A-rough-road-financial-crisis.pdf [Accessed: November 26, 2009].

Köksal, M. H. and Özgül, E. 2007. The relationship between marketing strategies and performance in an economic crisis. Marketing Intelligence \& Planning, 25(4): 326-342.

Langlois, R.N. 2003. The Vanishing Hand: The Changing Dynamics of Industrial Capitalism. Industrial and Corporate Change, 12(2): 351-385.

Laursen, K. and Salter, A. 2006. Open For Innovation: The Role of Openness in Explaining Innovation Performance Among U.K. Manufacturing Firms. Strategic Management Journal, 27: 131-150. 
New York Times. 2008. Automotive Industry Crisis. [Online] Available at: http://topics.nytimes.com/top/referenc e/timestopics/subjects/c/credit_crisis/auto_industry/index.html [Accessed: November 26, 2009].

Pearce, J.A. and Michael, S.C. 1997. Marketing strategies that make entrepreneurial firms recession-resistant. Journal of Business Venturing, 12(4): 301-314.

Pearce, J.A. and Michael, S.C. 2006. Strategies to prevent economic recessions from causing business failure. Business Horizons, 49: 201-209.

Pearson, C.M. and Clair, J.A. 1998. Reframing Crisis Management. Academy of Management Review, 23(1): 59-77.

Scania. 2009. Annual Report 2008. [Online] Available at: http://www.scania.com/Images/66684-EN_2008_lower s_tcm10-229950_50698.pdf [Accessed: November 26, 2009].

Scania Interim Report. 2008. January - September 2008. [Online] Available at: http://www.scania.com/Images/ Scania \%202008\%20Q3\%20report\%20FINAL_tcm10-219196_50680.pdf [Accessed: November 25, 2009].

Shrivastava, P. 1993. Crisis Theory/Practice: Towards a Sustainable Future. Industrial and Environmental Crisis Quarterly, 7: 23-42.

Teece, D.J. and Pisano, G. 1994. The dynamic capabilities of firms: an introduction. Industrial and Corporate Change, 3: 537-556.

Teece, D.J., Pisano, G. and Schuen, A. 1997. Dynamic capabilities and strategic management. Strategic Management Journal, 18: 509-533.

Teece, D.J. 2007. Explicating dynamic capabilities:the nature and microfoundations of (sustainable) enterprise performance. Strategic Management Journal, 28: 1319-1350.

Ulmer, R.R. 2001. Effective Crisis Management through Established Stakeholder Relationships. Management Communication Quarterly, 14(4): 590-615.

Volvo Group1. 2008. Six months ended June 30, 2008. [Online] Available at: http://www3.volvo.com/investors/ finrep/ interim/2008/q2/q2_2008_eng.pdf [Accessed: November 25, 2009].

Volvo Group2. 2008. Nine months ended September 30, 2008. [Online] Available at: http://www3.volvo.com/inv estors/finrep/interim/2008/q3/q3_2008_eng.pdf [Accessed: November 25, 2009].

Volvo Group. 2009. Report on operations 2008. [Online] Available at: http://www3.volvo.com/investors/finrep/ interim/2008/q4/q4_2008_eng.pdf [Accessed: November 25, 2009].

Wang, C. and Ahmed, P. 2007. Dynamic capabilities: a review and research agenda. International Journal of Management Reviews, 9: 31-51.

Winter, S. 2003. Understanding dynamic capabilities. Strategic Management Journal, 24: 991-995. 


\section{APPENDICES}

\section{Appendix I: The Automotive Industry}

The Role of Subcontractors. The relationship between the OEMs and their subcontractors has traditionally been described by a tier structure (see Figure III below). The structure entails that tier 1 subcontractors develop, manufacture, and deliver relatively complex systems directly to the OEM. Tier 1 subcontractors purchase components from tier 2 subcontractors (who, in turn, purchase components from tier 3 subcontractors). However, it instructive to note that, this structure merely describes the buyer-seller relationships in the supply chain and is not to be seen as an indicator of subcontractors' profitability or interdependence.

Historically, the relationship between OEMs and subcontractors has passed through three stages of structural evolution. It began with mass production where the OEMs owned and controlled the majority of the supply chain (introduced by Henry Ford in the 1920s). In the 1980s, lean production emerged where inventory was minimised through just-in-time deliveries which meant that subcontractor relationships became an essential quality issue. Today, the structure can be described as collaborative engineering and production where the OEMs use system integrators as business partners instead of restrictedly collaborating with their own supply base (see Figure IV below) (Gerst and Bundichi, 2004). In essence, this latest evolution can be explained by the automotive industry being a capital-intensive industry, forcing the OEMs to restructure their way of doing business. In conjunction with increased competition and reduced profits, more OEMs have acknowledged their brand has a major influence on their ability to charge a premium price in the future. This development has resulted in an increased outsourcing to and dependence on subcontractors, who are not only taking over production but also some of the processes associated with research and development (R\&D). As a result, the subcontractors currently develop and build 65 percent of the average vehicle, yet in 2015 they are expected to produce 77 percent of the total value. The idea from the OEMs perspective is to enhance core competences and to foster specialised subcontractors who can capitalise on economies of scale by delivering to more than one OEM (Denneberg and Kleinhans, 2007). Thus, whilst subcontractors are taking over more manufacturing processes, OEMs are able to increasingly focus on marketing, branding, financing and services towards the end customer.

The Swedish Automotive Industry. Sweden is highly dependent upon its automotive industry. From an international perspective the country is unique; with a population merely exceeding nine million, it has four of the world's largest vehicle producing companies (Volvo Cars, Volvo Trucks, Saab, and Scania) who have maintained production and R\&D facilities within the country. In 2007, the automotive industry employed around 140,000 people and every employee was said to create an additional 1.6 employment opportunities within other lines of trade. It is also the single largest R\&D investor in Sweden, contributing to 31 percent of the total expenditure within that field. However, the automotive industry itself is directly dependent upon exports and indirectly upon the global business climate. 85 percent of the cars and 95 percent of the trucks produced are sold on markets outside of Sweden, nearly amounting to 13 percent of Sweden's total exports (Bil Sweden, 2009).

FIGURE III: PREVIOUS TIER STRUCTURE

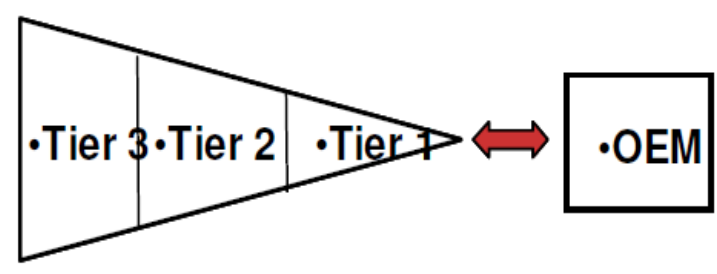

FIGURE IV: CURRENT TIER STRUCTURE

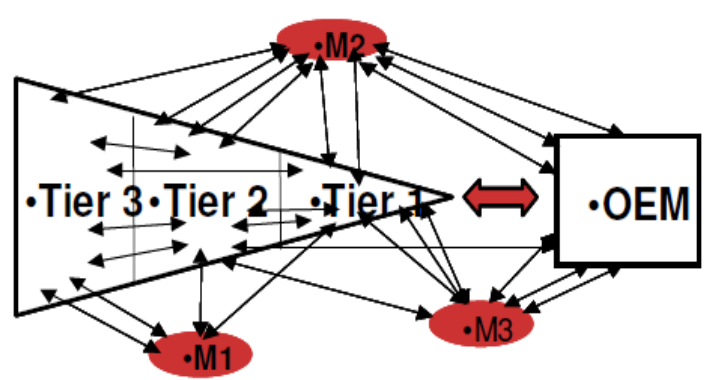

$M=$ system integrator

Both figures have been adapted from Gerst and Bundichi (2004). 
In 2008, the Swedish automotive industry has been under severe pressure. Volvo Cars, currently owned by American Ford Motor Company, faced losses of USD 736 million and has dramatically reduced their work force. As a result, Ford has announced that they are planning to sell Volvo Cars due to the turbulence in the industry. This change in ownership is set to be realised before the end of 2009 (Johnsen, 2009). In June, 2009, General Motors signed a memorandum of understanding to sell SAAB to Swedish sports car manufacturer Koenigsegg Group, a deal which is still under negotiation. Due to the uncertainty of SAABs future, their sales have continued to plummet and in June 2009 (when the European market rose by $2.4 \%$ ) SAAB displayed a decline of 62 percent (Pagnamenta, 2009).

Although the Swedish heavy vehicle producing companies were affected later, the same development occurred there. In one year, the capacity utilisation dropped from 94 to 59 percent (Statistics Sweden, 2009); in the summer of 2008, Volvo Trucks were producing at maximum capacity and was having problems meeting the exceptional demand. However, in the coming months the cancellations were outstripping the orders, resulting in a negative net order intake of 1,800 trucks for October and November. This sudden demand shock has forced Volvo Trucks to experience several weeks of non-production, not just in its largest markets (Europe and North America) but on a global scale (IHS Global Insight, 2008). In addition, Scania - Sweden's second heavy vehicle OEM - has faced similar problems but kept the layoffs to a minimum due to shorter working weeks and a company agreement to cuts salaries up to 20 percent (Joshi, 2009).

The Swedish Subcontractors. In 2007, there were around 1,100 Swedish automotive subcontractors who employed 85,000 of the 140,000 people working in the Swedish automotive industry. However, whilst the OEMs constitute 50 percent of the subcontractors' turnovers, only 25 percent of the Swedish OEMs' total purchases come from its Swedish subcontractors. This means that exporting to foreign OEMs is a relatively unexploited territory with enormous growth potential. This is a development that the Swedish OEMs are advocating, primarily because it would allow subcontractors to share technology and gain competitiveness and mean that OEMs can diversify some of their social responsibility. Some of the emerging trends among Swedish subcontractors include an increasing share of production in low wage countries, diversification into other businesses, and problems to finance investments. This is the result of an industry with shrinking margins, causing significant pressure not only on the OEMs but the entire supply chain. Since the crisis hit the Swedish automotive industry, subcontractors have made around 20,000 workers redundant. Moreover, 15 subcontractors have declared bankruptcy, 9 are under reconstruction, and 4 have left the country (Swedish Automotive Industry Association, 2009).

\section{Appendix II: The Emergence of Dynamic Capability Theory}

In the literature on strategic management, no concept has initiated as much academic consideration as that of the level of how to generate and sustain a competitive advantage. Historically, much research has been devoted to this quest from two diverse perspectives. The first, an 'industrial economics perspective' (e.g., Porter, 1980; 1985), argues that competitive advantage derives from firms' positioning of products, which allow them to defend against new entrants and rivals as well as earn bargaining power over suppliers and customers. The second, a 'resource-based view' (RBV) (e.g., Wernerfelt, 1984; Conner, 1991), focuses on internal resources and capabilities of the firm and argues that competitive advantage grows out of resources that are valuable, rare, inimitable, and non-substitutable (often referred to as 'VRIN' resources).

During the 1990s, however, the emergence of increasingly global and extremely competitive markets raised scepticism concerning the effectiveness of both these perspectives. Innovations and technologies breaking completely new ground were found to eliminate competitive advantages generated by both market positioning and distinguishing resources (Henderson and Clark, 1990; Leonard-Barton, 1992). Consequently, capabilities enabling rapid and accurate reconfiguration of resources were found to be vital elements of strategic management (Teece and Pisano, 1994). Such capabilities enable combining and integrating resources into unique clusters that develop distinctive abilities within a firm (Teece et al., 1997) and are referred to as dynamic capabilities. DCT can be seen as an extension of the RBV (Barney, 2001) which aims to reconfigure firms' resources in order to achieve both market positioning and creation of VRIN resources. 


\section{Appendix III: Financial Indicators}

Historically organisational performance has been simplified to only express success or failure (Venkatraman and Ramanujam, 1986). When this no longer was sufficient, 'return on assets' (Bettis and Mahajan, 1985; Dess and Robinson, 1984; Wallace, 1995) and 'growth in sales' (Dess and Robinson, 1984) has been commonly used to create a more differentiated picture of organizational performance. In our study, 'return on assets' has been replaced with 'net income / turnover', since a few companies only gave us restricted access to their financial situation and thereby indirectly prevented us from calculating it. Venkatraman and Ramanujam (1986) describe this problem and state that these 'gatekeepers' (CEOs not giving full access to researchers) are more common among private companies, forcing the researcher to use alternative measures. For this reason, and that we primarily measure and evaluate negative performance, we also included resilience (as measured by break-even) and two ratios describing their aggregated losses due to the crisis. We also provide indicators for comparison of their status prior to the crisis.

Financial status. The financial status displays a snapshot of the companies' short term ability to pay creditors (cash liquidity), and long term ability to survive (solvency), based on annual reports 2007. Hence, these indicators were used to appreciate the financial strength of the firms prior to the crisis. Ratio analysis is an established method to evaluate the future of a company and its risk of bankruptcy (Altman, 1968). Solvency shows the part of a firm's book value that is financed with equity, and it should under normal circumstances not be below 20 percent. During periods of particularly high growth, a lower ratio can be accepted but decreasing solvency together with low growth shall be treated as a clear warning signal of financial instability and as a threat to long-term survival. The average solvency within the automotive industry was 35 percent (Swedish Automotive Industry Association, 2009). Cash liquidity describes how well a firm can meet its short term obligations with current assets. If below 100 percent, a firm can be forced to take drastic measures; sell long term assets, or take out a rescue loan from a financial institute.

Growth. Growth in sales, or simply turnover change, is here measured compared to their position just prior to the crisis. Since every company realised decreasing sales in the crisis, it is actually a comparison of their respective sales contraction. We previously stated that every company within our sample lost between $60-80 \%$ of incoming orders due to the crisis, something our measure of turnover change should not be mistaken for. Turnover change is their expected turnover for 2009 in relation to the turnover they were heading for in 2008 (if the crisis had not struck).

Resilience. Traditionally, break-even has been used to control costs, identify functions that are not performing well, and to evaluate feasibility of potential projects (Pelfrey, 1990). In our study, we use it to measure how fast the firms managed to adapt to the new market conditions (i.e., significantly lower order intake). Our rationale was that if everyone is loosing money at the same point in time, the one reaching break-even first displays a higher resilience. We refer to break-even as the earnings before interest, tax, depreciation and amortisation (EBITDA), and it shows the first month after the crisis that their operational income no longer was negative.

Profitability. When calculating profitability (before and after the crisis) net income was used as the financial indicator, which is the profit after financial expenses attributable to shareholders. However, in order to create a comparable measure and protect participants' anonymity, the net income was divided by the turnover from the same year. This measure differs from the more established 'return on assets' by relating net income to sales instead of capital. Since we only compare results within the industry, where sales and capital can be assumed proportional, the consequences are moderate. This assumption is strengthened by tests we performed, with companies in our sample granting full access to their financial situation, indicating no difference between the measures. Furthermore, estimations are being used to compare net income for 2009. These estimations were done in October 2009. Nevertheless, when adequate objective measures are unavailable and performance cannot be excluded from the analysis, subjective measures can be used to assess at least two aspects of organisational performance. Dess and Robinson (1984) found that there is a significant correlation (at a $p<0.01$ level) between objective and subjective measures when it comes to return on assets and growth in sales. Since net income is the estimated, and partially subjective, part of our chosen measure, and the common denominator with 'return on assets', our measure is motivated.

Losses. Every company within our sample realised losses due to the crisis. To show the relative size of their individual losses and the extent to which they were affected by it, we use two measures. The first measure, 'aggregated losses / turnover 2008', juxtaposes the aggregated number of their respective losses during the crisis. It is also comparable our measure of profitability, since it relates to turnover and contains data from a period of one year. The second measure, 'aggregated losses / average net income before crisis', shows the severity of the firms' aggregated losses in relation to the average net income between $2005-2007$. We used an average from three years to 
balance out results from unrepresentative years. Obviously, profitable firms prior to the crisis were not as affected by the losses, in this ratio. When assessing the result from losses, companies with the lowest ratios (i.e. smallest losses, and highest profitability prior to the crisis in comparison to these losses), were seen as better performing.

\section{Appendix IV: Methodological Considerations}

The intention of this paper is not to provide a perfect relationship between managerial practices and performance in an economic crisis, but rather to reveal a piece of evidence on this relationship using knowledge from both theory and practice that may complement future accumulation of data. A central element in our approach has been that individuals actively contribute to the creation of their own social realities (Berger and Luckman, 1966), and thus, that managers' perceptions of the external environment are likely to have influenced organisational responses during the crisis. Consequently, in-depth interviews were used to gain insight into how managers both acted in and interpreted the crisis (Gould et al., 1974; Snow and Andersson, 1987). Yet, it is instructive to note that, this method implies that the results are confined to how things are remembered by the participants (Thompson et al., 1989), and should therefore be regarded as tentative. It is also essential to acknowledge that using an interview technique implies that not only the participants but also the researchers may affect the results. Thus, in order to minimise such influences, the participants' answers have been kept in their original state through audio recordings (when permitted by the participants) and/or detailed field notes. These data sets were then repeatedly analysed to capture the essence of each unique respondent and to separate the researchers' contributions from the results (Miles and Huberman, 1994).

\section{Appendix References}

Altman, E.I. 1968. Financial Ratios, Discriminant Analysis, and the Prediction of Corporate Bancrupcy. The Journal of Finance, 23(4): 589-609.

Barney, J.B. 2001. Is the resource-based 'view' a useful perspective for strategic management research? Yes. Academy of Management Review, 26(1): 41-56.

Berger, P.L. and Luckman, T. 1967. The social construction of reality. New York: Anchor Books.

Bettis, A.R, and Mahajan, V. 1985. Risk/Return Performance of Diversified Firms. Management Science, 31(7): 785-799.

Bil Sweden. 2009. Bilbranchen just nu. [Online] Available at: http://www.bilsweden.se/web/Bilbranchen_nr_1_2009 .aspx [Accessed: November 26, 2009].

Conner, K. R. 1991. A Historical Comparison of Resource-Based Theory and Five Schools of Thought Within Industrial Organization Economics: Do We Have a New Theory of the Firm?. Journal of Management, 17: 121-154.

Dennenberg, J. and Kleinhans, C. 2004. The coming age of collaboration in the automative industry. Mercer Management Journal, 17: 88-90.

Dess, G.G, and Robinson, R.B. 1984. Measuring Organizational Performance in the Absence of Objective Measures: The Case of the Privately-Held Firm and Conglomorate Business Unit. Strategic Management Journal, 5(3): 265-273.

Gerst, M. and Bunduchi, R. 2004. The Adoption of Standardised Technology in the Automotive Industry. In Paul Cunningham and Miriam Cunningham (Ed.), E-Adoption and the Knowledge Economy: Issues, Applications, Case studies: 287-294. Amsterdam: IOS Press.

Gould, L.C., Walker, A.L., Crane, L.E. and Lidz, C.W. 1974. Connections: Notes from the Heroin World. New Haven: Yale University Press.

Henderson, R.M. and Clark, K.B. 1990. Architectural innovation: The reconfiguration of existing product technologies and the failure of established firms. Administrative Science Quarterly, 35(1): 9-30.

Johnsen, T. 2009. It's official: Ford aims to sell Volvo by the end of the year and not to Volvo. [Online] Available at: 
http://www.thetruthsaboutcars.com/its-official-ford-aims-to-sell-volvo-by-the-end-of-the-year-and-not-tovolvo/ [Accessed: November 26, 2009].

Joshi, M. 2009. Heavy-vehicle maker Scania mulls wage cuts to avert job losses. [Online] Available at: http//www.top news.in/heavyvehicle-maker-scania-mulls-wage-cuts-avert-job-losses-2152344 [Accessed: November 24, 2009].

Leonard-Barton, D. 1992. Core capabilities and core rigidities: A paradox in managing new product development. Strategic Management Journal, 13: 111-126.

Miles, M.B. and Huberman, A.M. (Eds.) 1994. Qualitative data analysis: an expanded sourcebook. Thousand oaks, CA: Sage.

Pagnamenta, R. 2009. Saab may go bust in 10 days, warns GM. [Online] Available at: http://business.timesonline.co. uk/tol/business/industry_sectors/engineering/article5757562.ece\# [Accessed: November 28, 2009].

Pelfrey, S. 1990. Cost Categories, behavior patterns, and break-even analysis. The Journal of nursing administration, 20(12): 10-14.

Porter, M.E. 1980. Competitive Strategy: Techniques for Analysing Industries and Competitors. New York: Free Press.

Porter, M. E. 1985. Competitive Advantage: Creating and Sustaining Superior Performance. New York: The Free Press.

Snow, D.A. And Anderson, L. 1987. Identity work among the homeless: The verbal construction and avowal of personal identities. American Journal of Sociology, 92: 1336-1371.

Statistics Sweden. 2009. Industrial capacity utilisation, second quarter 2009. [Online] Available at: http://www.pubkat .scb.se/Pages/PressRelease 277843.aspx [Accessed: November 29, 2009].

Swedish Automotive Industry Association. 2009. Den globala fordonsindustrin. [Online] Available at: http://www.fkg.se [Accessed: November 29, 2009].

Teece, D.J. and Pisano, G. 1994. The dynamic capabilities of firms: an introduction. Industrial and Corporate Change, 3: 537-556.

Teece, D.J., Pisano, G. and Schuen, A. 1997. Dynamic capabilities and strategic management. Strategic Management Journal, 18: 509-533.

Thompson, C.J., Locander, W.B. and Pollio, H.R. 1989. Putting consumer experience back into consumer research: The philosophy and method of existential-phenomenology. Journal of Consumer Research, 16: 133-146.

Venkatraman, N, and Ramanujam, V. 1986. Measurement of Business Performance in Strategy Research: A Comparison of Approaches. The Academy of Management Review, 11(4): 801-814.

Wernerfelt, B. 1984. A resource-based view of the firm. Strategic Management Journal, 5(2): 171-180.

Wokutch, R.E, and McKinney, E,W. 1991. Bahavioral and perceptual measures of corporate social performance. Research in Corporate Social Performance and Policy, 12(2): 309-330. 


\section{VARFÖR HAR VISSA UNDERLEVERANTÖRER KLARAT KRISEN I FORDONSINDUSTRIN BÄTTRE ÄN ANDRA?}

Den 24 oktober 2008 presenterade Volvo Lastvagnar och Scania sina rapporter för det tredje kvartalet, vilket blev starten på krisen i den tunga fordonsindustrin. Krisen var oväntad för de allra flesta och slog med en förödande kraft mot de svenska under-leverantörerna. Nu - ett drygt år senare - har flertalet underleverantörer gått $\mathbf{i}$ konkurs, men samtidigt har andra lyckats vända krisen till sin fördel och rapporterat stadiga vinster. Dessa skillnader kan bland annat härledas till företagens uppfattning av sig själva i leverantörskedjan: Är man som underleverantörer en isolerad enhet vars uppgift är att effektivt leverera utefter sina kunders prognoser, eller kan man genom extern informationsinhämtning och omvärldsanalys skaffa sig en egen uppfattning om framtiden och anpassa organisationen efter den?

Våren 2008 gick de svenska under-leverantörerna till den tunga fordonsindustrin på högvarv, och prognoserna för slut-producenterna (Volvo Lastvagnar och Scania) visade inga tecken på förändringar. Följaktligen producerade många underleverantörer i femskift och investerade kraftigt för att följa med i sina kunders utveckling. I kontrast till personbilsindustrin som upplevde en kraftigt minskad efterfrågan och realiserade stora varsel vid den här tiden, såg den tunga fordonsindustrin lovande ut.

Denna bild visade sig vara helt felaktig. Mest anmärkningsvärt var att Volvo Lastvagnars inkommande orders i Europa hade fallit från 21948 stycken (kv. 2) till 115 stycken (kv. 3) (Volvo Group2, 2008). För underleverantörerna orsakade detta så pass allvarliga och oväntade fall av orders att industrin praktiskt taget över en natt paralyserades. Krisen blev ett faktum och nio månader senare hade svensk fordonsindustri tappat $20 \quad 000$ arbetsplatser (av 85000 innan krisen), 15 underleverantörer hade gått i konkurs, 9 hade gått i rekonstruktion, och 4 lämnat landet.

Vid denna tidpunkt förlorade några företag fortfarande flertalet miljoner kronor i månaden, medan andra hade iscensatt en återhämtning som genererade miljoner i positivt kassflöde. Eftersom samtliga företag $\mathrm{i}$ denna undersökning hade en likvärdig exponering till krisen, är det svårt att förstå varför de presterade så olika. Hur hanterade de svenska underleverantörerna till tung fordonsindustri den ekonomiska kris de ställdes inför hösten 2008, och varför varierade deras prestationer så kraftigt?

\section{Undersökningsmetod}

Effekten av ekonomiska svängningar kan minskas genom att diversifiera verksamheten geografiskt eller till andra branscher (Pearce and Michael, 2006). För att möjliggöra en undersökning av ytterliggare faktorer pekade Fordons Komponent Gruppen (FKG) ut 11 underleverantörer med en likvärdig exponering till krisen. När datainsamlingen genomfördes noterades att endast sju av företagen nådde upp till de ställda kraven, och resterande fyra plockades bort. Därmed kunde nu samtliga företag, innan krisen, hänvisa minst 65 $\%$ av omsättningen till den tunga fordonsindustrin varav 50 \% kom från Scania, Volvo Lastvagnar, eller båda. Som ett resultat såg företagen, när krisen slog till hösten 2009 , att sina in-kommande orders minskade med $60-80 \%$.

\section{Underleverantörernas likartade arbetssätt}

För att kunna planera verksamheten och arbeta effektivt får underleverantörerna kontinuerliga uppdateringar på sina kunders produktionsprognoser 48 veckor framåt. Man får även information om hur man kan utveckla sina produkter och processer genom att göra kundbesök, deltaga i mässor och utställningar, samt besöka seminarier organiserade av branschorganisationen FKG. Ett liknande mönster kunde urskönjas i företagens sätt att hantera krisen. Varje företag började med att bilda en krisgrupp. Här försökte man överblicka situationen genom att kontakta kunder, leverantörer, och 
kontakter inom FKG. Sedan ställde man sig frågan "hur påverkar detta oss?" För att besvara den genomfördes kostnads- och break-even analyser. Till sist försökte man anpassa organisationen utefter analyserna. Anpassningen innebar ett omedelbart inköps- och investeringsstopp, man frös/reducerade löner, varslade personal, och tog till alla knep man kunde för att förbättra likviditeten. Detta var ingen linjär process utan den genomfördes stötvis i samband med att ny information om krisen offentliggjordes eller inhämtades.

\section{Fyra helt olika resultat identifieras}

Trots att företagen drabbades lika hårt av krisen, och att man försökte anpassa sig till de nya förhållandena i ett likartat arbetssätt, så varierade deras resultat kraftigt. För att tydliggöra de skillnader $\mathrm{i}$ beteende och krishantering som identifierats, kommer nu fyra av företagen att beskrivas mer ingående (namnen är påhittade), samt deras resultat att presenteras (se nedan).

Proddex $\boldsymbol{i}$ konkurs. Proddex är ett medelstort företag som traditionellt sätt har fokuserat på att genom effektivitet och kvalitet tillfredsställa sina kunder. Före krisen hade man en genomsnittlig vinst på 2 miljoner (2005 - 2007) och en tillväxt på 20 \% (2007). VD:n beskrev krisen som "en blixt från klar himmel som träffade oss vid sämsta tänkbara tillfälle". 2009 har man tvingats till konkurs, återuppstått i ny regi, men redovisar trots det en förlust på 20 miljoner.
För att följa med i kundernas utveckling genomförde man innan krisen den största investeringen i företagets historia. En investering som möjliggjordes av de nya finansiellt starka utländska ägarna. Syftet med det nya ägarskapet var inte endast att få tillgång till kapital, utan enligt Proddex VD "att eftersom marknaden var så pass stabil skulle vi bara fokusera på utveckling av interna processer, medan det utländska huvudkontoret med sin erfarenhet och sitt stora kontaktnät skulle identifiera strategiska möjligheter". När krisen sedan utvecklade sig fick Proddex stora problem med att överblicka situationen och att anpassa organisationen därefter. Det utländska huvudkontoret visade ingen vilja att hjälpa dem. Likviditetsproblemen växte och trots att man varslade personal vid fem olika tillfällen tvingades man till konkurs i maj 2009. Företaget behölls dock intakt och rekonstruerades en vecka senare under nya ägare. "Vi har lärt oss att inte blint lita på våra kunders prognoser, utan vi måste utveckla processer till att skapa vår egen framtidsplanering", sa VD:n som fortfarande är den samma.

Lastia klarade sig precis. Lastia är ett litet företag som är stolta över sina kunskaper om marknaden och branschen. Innan krisen visade man en genomsnittlig vinst på två miljoner (2005 - 2007), samt en omsättningstillväxt på 22 \% (2007). Trots att man tidigt fick indikationer på en nedgång, så förväntas man göra en förlust på 3,5 miljoner kronor 2009.

\section{Årets resultat / omsättning}

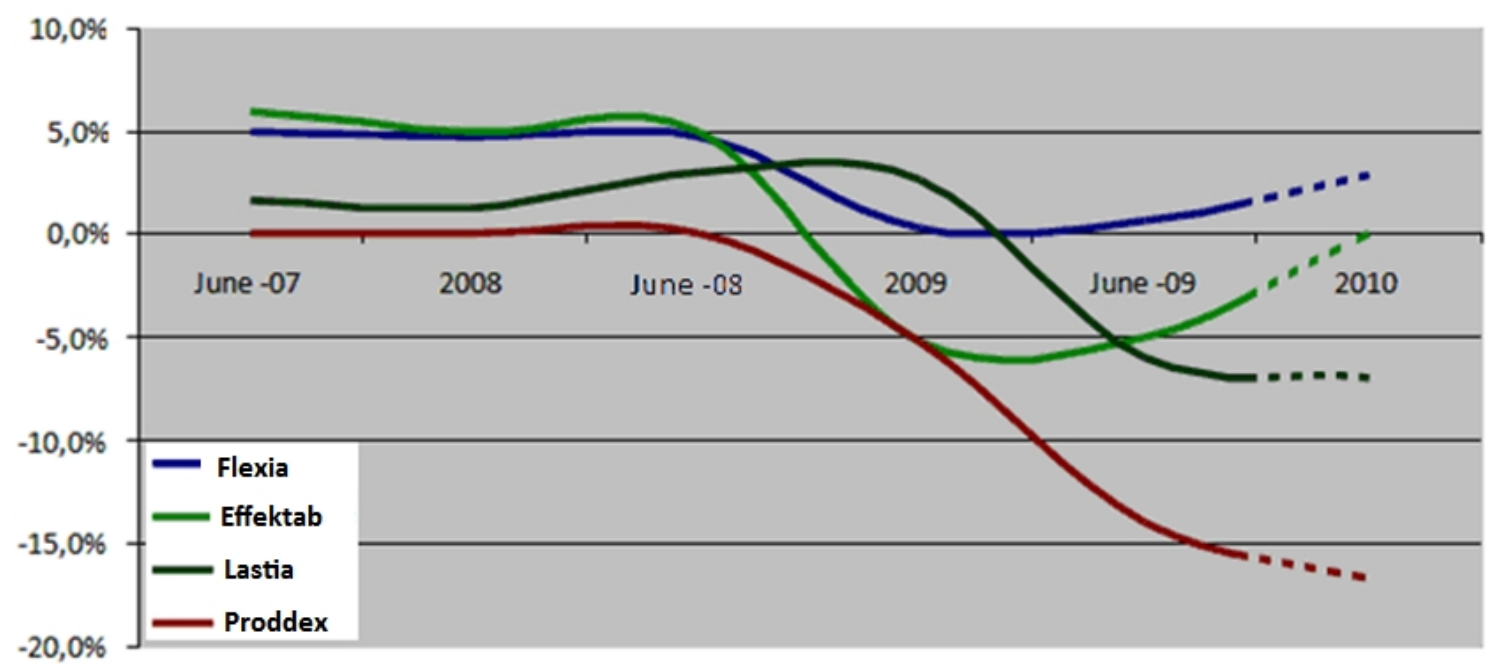


Sommaren 2008 fick VD:n, som arbetat hela sitt liv inom fordonsindustrin, genom sitt breda sociala nätverk (både inom och utanför landet) indikationer på en nedgång. Ändå förblev företaget passivt ända in i krisen. I Lastia hade man nämligen inget strukturerat format för affärs- och marknadsanalys. Extern information spreds informellt vid frukostmöten, som VD:n sedan tog beslut utifrån. Han var "spindeln i nätet", som marknadschefen uttryckte det. När krisen sedan utvecklade sig hade man stora problem att överblicka dess omfattning, vilket resulterade i att endast $30 \%$ av de totala varslen gjordes i december och resterande $70 \%$ i april 2009. Sammanlagt har man förlorat 5,5 miljoner i krisen och resultatet 2009 kommer att bli negativt. "Vårt jobb är att producera det våra kunder säger att vi ska producera, vi kunde inte ha gjort annorlunda", svarade VD:n på frågan varför de inte agerade på de tidiga indikationerna.

Effektab såg möjligheterna. Effektab är ett litet företag med en genomsnittlig vinst på 3 miljoner innan krisen (2005 - 2007), och en tillväxt på $12 \%$ (2007). Hösten 2008 litade man fullt ut på sin största kund Scanias prognoser och förberedde inte organisationen på nedgång. Trots det lyckas man prestera ett nollresultat 2009.

Ett par år innan krisen började man att aktivt samla, bevaka, och utvärdera extern information. Detta har skett i form månatliga affärsanalyser från marknadschefen, teknik- och management konsulters hjälp att hitta nya processer och möjligheter, fler personers engagemang $i$ att leta möjligheter och ta beslut om investeringar, samt standardiserad instrumentation för att hämta in och kategorisera nyheter om industrin och kunderna. "Idén var att inte bli för bekväm i de långsiktiga relationerna utan att öka proaktiviteten på marknadsavdelningen", förklarade marknadschefen. Efter sommaren 2008 började man misstänksamt betrakta kundernas prognoser. Man blev dock försäkrade av Scania om att prognoserna inte behövde justeras, att den dåliga försäljningen endast berodde på årstiden, och Effektab förblev därmed passiva. I början av 2009 realiserade man dock krisen som ett faktum och de redan etablerade kanalerna för inhämtning och analys av extern data började att användas.
Situationen analyserade i samarbete med banken och konsulter, och $60 \%$ av varslen genomfördes direkt. Samtidigt beslöt man att fortsätta sin prioritering och satsning på marknad/försäljning för att "visa oss starka när andra är svaga", som marknadschefen uttryckte det. Arbetet resulterade i flertalet nya kunder och orders, både inom och utanför fordonsindustrin. "Vi har en bättre position idag än innan krisen", sa marknadschefen.

Flexia anpassade sig snabbt. Flexia är ett medelstort företag som alltid har fokuserat på strategiskt arbete och affärsutveckling. Innan krisen växte omsättningen med anmärknings-värda $48 \%$ (2007), vilket minskade deras egna kapital till risknivå. Trots detta räknar man med en vinst på 13 miljoner 2009. Hur kunde Flexia överträffa de andra?

I motsats till de andra företagen arbetar man här aktivt med att förutspå marknadens utveckling genom insamling och bearbetning av extern data; marknadsanalyser från nyckelföretag i relaterande branscher, månadsprognoser från banken, flertalet databaser, Riksbanken, ett tiotal nyhetsprenumerationer, oljepris- och lastbilsregistreringstrender, rapporter och analyser från Global Insight, och så vidare. Data insamlas och analyseras av ett femtontal personer (ledning, marknad, och försäljning) som bidrar med kunskap ifrån sina respektive områden för att upptäcka affärsmöjligheter och skapa en scenarioplanering. Inför krisen 2008 var man förberedd, och redo att klara av, en nedgång på $17 \%$. När situationen visade sig vara betydligt värre kunde man snabbt justera sin scenarioplanering och ta omedelbara beslut. Samtliga varsel gjordes 2008 (och rätt personal kunde behållas då man inför facket motiverade kompetens utefter ett etablerat utvärderings-system), löner och arbetstider reducerades, samt avskrivnings perioder förlängdes (man hade gjort kraftiga avskrivningar tidigare som en förberedelse inför krisen). "Jag tror inte att vi var de enda som misstrodde slutproducenternas optimistiska prognoser, men vi var nog relativt ensamma om att våga göra förberedelser innan krisen var ett faktum", summerade Vd:n.

\section{Bredare och djupare kunskap}

Resultaten indikerar att företagens prestation $\mathrm{i}$ 
krisen har påverkats av deras förmåga att söka och agera på extern information. Proddex missöde verkar bero på deras oförmåga att upptäcka förändringar i marknaden, samt på saknaden av processer att behandla sådan information. Lastia å andra sidan, märkte genom sin VD:s stora kontaktnät att krisen var på väg men hade inga standardiserade processer inom företaget till att ta snabba och korrekta beslut på informationen. Detta ledde till en långsam organisatorisk anpassning och stora förluster. I motsats till Lastia såg Effektab inte krisen i tid utan litade på sin största kunds optimistiska prognoser. När krisen sedan slog till däremot, kunde man använda sina etablerade rutiner till att snabbt analysera situationen och genomföra nödvändiga åtgärder. Man såg bortom sin närmsta verklighet, kunderna och leverantörerna, och tog hjälp av andra intressenter (banken och konsulterna) för att få djupare kunskap om marknaden. Detta resulterade i en enastående återhämtning 2009. Slutligen, Flexias starka prestation verkar ha påverkats av att man inhämtade bredare kunskap om marknaden till att komplettera kundernas prognoser (ex. makro analyser, relaterade branschanalyser) för att förutse och förbereda sig på svängningar, men även av de etablerade rutiner som gjorde att man snabbt och korrekt kunde ta beslut när information dök upp (scenarioplanering, utvärderingssystem).

\section{Känn av, och grip tag!}

Genom samma tankesätt indikerar resultatet på att förmågan att känna av miljön, och gripa tag $i$ möjligheter, har format underleverantörernas prestation i krisen. För att skapa en mer korrekt bild av omvärlden (känna av) har vissa hämtat både bredare och djupare kunskap ifrån marknaden. För att sedan ta vara på möjligheter (gripa tag), eller skydda sig mot hot, har vissa använt etablerade processer för att implementera välgrundade beslut och anpassa företaget till den skiftande yttre miljön. Det verkar även finnas en samverkan mellan de två förmågorna, exemplifierat av Flexia, som inte bara var framträdande på grund av processer som effektivt behandlade den externa informationen, utan framförallt för att informationen var korrekt. Vidare visar resultatet även att de som hade dessa förmågor, och därmed effektivt kunde hantera krisen, även kunde behålla satsningar på marknadsföring och försäljning. De visade helt enkelt kraft när andra var svaga, och tog nya marknadsandelar.

\section{Idag är ett resultat av besluten vi tog igår}

Företagsledarna i undersökningen visade sig ha två helt olika uppfattningar om sin roll $i$ leverantörskedjan. Proddex och Lastia inriktade sig på att så effektivt som möjligt tillfredsställa sina kunder, medan Effektab och Flexia primärt fokuserade på att kontinuerligt finna nya sätt att skapa värde. När krisen sedan utvecklade sig, ökade samtligas behov av att samla extern information och få en uppfattning om krisens dignitet. Nu var det inte längre tillräckligt att bara följa kundernas prognoser. Man tvingades samla, analysera och agera på information helt självständigt. Eftersom detta är processer som utvecklas med tiden, fick de företag som inte hade etablerade rutiner innan krisen det svårt. I motsats till dessa kunde de företag som var vana vid att samla och agera på extern information i syfte att finna nya affärs-möjligheter, använda samma kanaler och interna processer för att anpassa sig till krisen. Besluten de tog långt innan krisen formade helt enkelt deras resultat $i$ krisen. Därmed finns det indikationer på att man som underleverantör bör skaffa sig en egen bild av framtiden, genom extern informationsinhämtning och marknadsanalys, så att man när marknaden svänger kan anpassa organisationen utefter.

\section{Referenser}

Pearce, J.A. and Michael, S.C. 2006. Strategies to prevent economic recessions from causing business failure.

Business Horizons, 49: 201-209. 